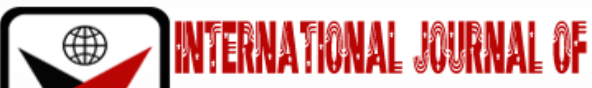

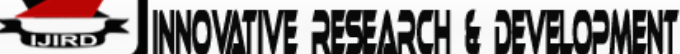

ISSN 2278-0211 (Online)

\section{Framing of National Disasters in the Print Media}

\begin{tabular}{c}
\hline Stephen Osei Akyiaw \\
Lecturer, Department of Graphic Design, \\
University of Education, Winneba, Ghana \\
Abena Abokoma Asemanyi \\
Lecturer, Department of Communication and Media Studies, \\
University of Education, Winneba, Ghana \\
Ahmed Taufique Chentiba \\
Lecturer, Department of Communication Sciences, \\
University of Development Studies, Ghana
\end{tabular}

\begin{abstract}
:
The study examined how National Disasters are framed in the print media, specifically the Daily Graphic newspaper in Ghana. The period of study was January and June 2015 respectively. The January 2015 National Disasters was termed as Fire Outbreaks while the June 2015 National Disasters was framed as Twin Disasters. A total of 43 disaster news stories were analysed for this study. Out of the total number, 9 headline stories were analysed in the month of January 2015 and 34 headline stories were looked at in the month of June 2015.Five (5) themes emerged through Content Analysis. The study revealed that the theme of Action featured more than the other themes which are Fear, Violence, Sympathy and Confusion. Finally, the study showed the number of days disaster news headlines lasted in the Daily Graphic during the period stated above. It was revealed that the Fire Outbreaks in January 2015 appeared in the Daily Graphic for 8 days while the Twin Disasters appeared in 16 days in June 2015.
\end{abstract}

Keywords: Disaster, Ghana, newspapers, frame, coverage, headline

\section{Introduction}

Media is one of the most important institutions in every society. The media plays a vital role in the dissemination of information to the public. The print media, which forms part of the channels of mass communication has been the major source of disseminating information since the inception of the movable press by Johan Gutenburg in 1440 .

To date, the print media still serve as one of the valuable sources and powerful modes of communication. This power controls much of what people understand of events that occur around the world on a daily basis. The newspaper being the main form of print media is a major medium for sending authentic news items to its publics. Thus, the Ghanaian public depend on newspapers to know the various happenings in the country which include issues on politics, religion, human rights, disaster among others.

The public trust the information provided by media during disaster so they often access media for disaster updated information. According to Fernando (2010), the media stand to gain substantial audiences at moments of natural disaster. Media coverage on disasters are captured for shorter periods of time than they do on other issues. Numerous disasters suffered by Ghana were framed in the newspapers by emphasizing government response than addressing individuals' and communities' level of response. The focus of this study is to examine how the print media, specifically Daily Graphic Newspaper framed National Disasters in Ghana.

The Daily Graphic is a state-owned Newspaper Agency with the largest daily circulation and readership in Ghana (NMC, 2006). The 2018 GeoPoll report found that Daily Graphic, published by The Graphic Communications Group Ltd., was the most popular daily newspaper, at 1.5 million readers per day (GeoPoll, 2018). The paper is the company's premier newspaper, published since October 2, 1950. To date, it is regarded as the most credible and authentic source of news in Ghana.

Newspapers capture and frame disaster stories differently depending on their coverage and sources of information. Space and time of news framing, however, is very essential in news item in the newspapers and essential for communication research as it signify salience in the news making process. The space and time frames allow researchers to compare how different types of issues and events are framed. Chyi and McCombs (2004) explain 'as 'time' corresponds to the 'when' in the five W's of journalism, 'space' refers to the 'where' and may also include the 'who,' the 'what,' and even the 'why'. Gitlin (1980) notes that framing is unavoidable because, at the institutional and individual journalist level, framing is necessary to interpret, organize, and understand large amounts of information. Entman (1993) suggested that framing functions to define problems, diagnose causes, make moral judgments, and suggest remedies. Houston, 
Pfefferbaum and Rosenholtz (2012) aver that when issues and events are covered in the news, the frames used generally change so that different aspects of the issues or events are emphasized at different points in time, a process known as frame changing. They further assert that frames tend to change because there are different orientations towards public issues and events depending on how well those issues and events are known.

When a disaster occurs, the role of the print media is understood to include communicating the warning that is available; providing a description of what occurred, keeping the public informed on post event, and even contributing to individual and community recovery and community resilience. The manner in which disasters are framed in the print media can signify whether the media understand the disaster. Additionally, these frames may influence how the general public understand and respond to disasters and how disasters recovery unfolds. Agonal (2013) notes that the media generates myths of their involvement in the wake of any disaster. Thus, they are the first to reach and rescue the victims of natural disasters, give updates and current developments on the scene with the audience. Knowing this, the public most often rely on media for accessing disaster updated information and also trust the information provided. This therefore begs the question of how the issues emanating from disasters are framed in the media.

Ghana lost its main medicines and medical supplies depot on January 13, 2015. The loss was as a result of a fire outbreak that gutted GH\$100 million worth of drugs. On June 3, 2015, the city of Accra again witnessed two days of heavy downpour resulting in flooding that left many homeless and without power. The flooding hampered rescue efforts and may have led to the fire that claimed the lives of many. A total of 150 people were reported to have died in the inferno. These disasters were reported in the media with several frames to keep the audience informed on happenings at the disaster sites.

While reviewing literature, there appears to be minimal works on disaster framing in the print media in Ghana. Thus, this study examined how disaster, particularly the January and June 2015 disasters, was framed in the Ghanaian premier newspaper, the Daily Graphic and also ascertained the prominence and frequency of coverage allocated to disaster news stories.

\section{Literature}

\subsection{Disasters and Types of Disasters}

\subsubsection{Natural Disasters}

Hydro-meteorological Disasters, Pest and Insect Infestation Disasters, Geological/ Nuclear Radiological Disasters, Fires and Lightning Disasters, Disease Epidemics Disasters.

\subsubsection{Man-Made Disasters}

Ethnic conflicts, War, Aviation and lake/maritime accidents, Pollution of water bodies, Industrial accidents, Failure of structures (collapse of buildings, dams and mines), Nuclear and radiological accidents and Oil spillage. The disasters of 2015 can be categorized under the Natural Disasters, specifically, Hydro-meteorological disasters.

\subsection{Disasters and the Media}

Ali (2013) posits that the "media have always been concerned with events and stories which have human impact. Natural disasters in some sense have the most impact as they destroy a large volume of human and material elements." Even before television, news pictures like the explosion of the Hindenburg captured the attention of audiences (Scanlon, 2007). The media draws a clear picture of how disasters affect its readers because of how they frame the headlines and display pictures. Disasters have been part of media discourse ever since there were newspapers (Ali, 2013). More broadly, media have the capacity to enhance public discourses of compassion that can potentially influence individuals' readiness to give a helping hand to others affected by the disaster (Cohen, Ball-Rokeach, Jung, \& Kim, 2002). Liebes (1998) notes that as soon as a big disaster hits, media suspend regular programming and start broadcasting "disaster marathons". Disasters Marathons refers to the media house that broadcast disaster news early and the frequency of coverage they allocate for the news. By so doing, an agenda is set for the public to shift attention to the disaster issue.

News coverage of a disaster is not sustained for long, and that the news media focus on dramatic descriptive qualities of the events rather than upon causal explanations (Ploughman, 1995). Ali (2013) also avers that reporters are largely interested in collecting data and information about damage, destruction and casualties even when no one is yet to be very clear about a situation in the early stages of a disaster. Media personnel are trained to gather information. Moreover, they are also trained to compete. They jump into an unknown situation to capture the story in the rush of being the first reporter or media house to break the original and exclusive news to the public. Media can also enhance public awareness and facilitate public assistance in local communities (Brown \& Minty, 2006; Oosterhof, Heuvelman, \& Peters, 2009). The media encourage positive behaviours from their audience in times of disasters. According to Perez-Lugo (2004), the media also play a pivotal role in relieving the psychological stress of the victims by providing emotional support and developing social connection to disaster victims. In as much as the media play a huge role in broadcasting disaster news stories quickly, their act also go goes further to relieve the psychological stress of victims and affected family members, they also consider the truthfulness and credibility of their sources of information.

\subsection{Theoretical Framework}

The Framing Theory and the Agenda Setting Theory form the theoretical basis of this study. The Framing theory is intertwined with Agenda Setting Theory and they have become increasingly popular in news stories analysis. According to 
Cissel (2012), ErvingGoffman was the first to give attention to framing as a form of communication. The framing theory was first put forth by Goffmanin 1974under the title Framing Analysis. Entman (1993) states that "framing involves the selection of "some aspects of a perceived reality" that makes those aspects more salient to a media consumer." When disasters occur the media chooses to highlight a part of it and leaves the rest. Chong and Drukman (2007) refers to framing as the process by which people develop a particular conceptualization of an issue or reorient their thinking about an issue. Framing is an influential way of forming and shaping public opinion. It means to put emphasis on certain features of news to the denial of other news. Gitlin (1980) describes the framing process as" principles of selection, emphasis and presentation composed of little tacit theories about what exists, what happens and what matters". This accretion was also made by Tankard (1985) who defined a media frame as "a central organizing idea for news content that supplies a context and suggests what the issue is through the use of selection, emphasis, exclusion, and elaboration.

Scheufele and Tewksbury (2007) gave credit to Entman as offering a detailed explanation of how media provides audiences with schemas for interpreting events. Subsequently, Entman (1993) notes that news organizations frame reality by making judgements on inclusion, exclusion, illumination, and suppression. Kuypers (2006) observed that those who frame facts or events think that other people will perceive facts or events in their intended ways. As Gross (2006) asserted, frames will be highlighting certain aspects of an event or policy, guide audience member's thoughts about the event or issue in predictable ways, to predictable conclusions. Gitlin (1980) notes that framing is unavoidable because, at the institutional and individual journalist level, framing is necessary to interpret, organize, and understand large amounts of information. Entman (1993) suggested that framing functions to define problems, diagnose causes, make moral judgments, and suggest remedies. D'Angelo et al. (2019) finally aver that framing is the theoretical base that has reignited scholarly attention to visual communication in the last two decades.

Guided by this theory, this study examines the various frames to the disaster stories of January 2015 and June 2015 by the Daily Graphic newspaper to ascertain the salience given to aspects of the disaster and the intended response from the public.

\subsection{Agenda Setting Theory}

According to the Agenda-Setting Theory, propounded by Maxwell McCombs and Donald Shaw in the 1970s, media set the agenda for public opinion by highlighting certain issues. The principal of agenda setting was conceived and sketched by Walter Lippmann in his 1922 classic, Public Opinion, which began with a chapter titled The World Outside and the Pictures in Our Heads. Lippman (1922) proposed that people are not able to deal effectively with the variety and subtlety of their environment. He further argued that "the mass media are the link between world events and the pictures of these events in people's minds. The news media are a primary source of those pictures in our heads about the larger world of public affairs, a world that for most citizens is "out of reach, out of sight, out of mind." (Lippman, 1922). McCombs (1972) posits that newspapers provide a host of cues about the salience of the topics in the daily news, that is, lead story on page one, other front-page display, large headlines, etc. The Agenda-Setting Theory comes from a scientific perspective, because it predicts that if people are exposed to the same media, they will place importance on the same issues. According to Chaffee and Berger's (1997) criteria for scientific theories, Agenda-Setting is a good theory. The theory has explanatory power because it explains why most people prioritize the same issues as important. It has predictive power because it predicts that if people are exposed to the same media, they will feel the same issues are important. The theory is parsimonious because it is not a complex one, and it is easy to understand. According to Chaffee and Berger, the theory can be proven false. Furthermore, if people are not exposed to the same media, they will not feel the same issues are important. The meta-theoretical assumptions of Agenda Setting are balanced on the scientific side. The theory has organizing power because it helps organize existing knowledge of media effects.

Agenda Setting looks at the operation of the media which results in prioritization of issues that arise and engage the attention of the society (McQuail, 2005). McQuail subsequently explains that issues focused upon by the media become the issues that the public accepts as important for attention and discussion. McCombs and Shaw (1977) also posit that the mass media may not be successful in telling us what to think, but they are stunningly successful in telling us what to think about. Littlejohn (2002) on the other hand states that the media agenda affects the public agenda, and the public agenda affects the policy agenda. Additionally, if the media has close relationship with the elite society, the society will probably affect the media agenda and the public agenda in turn. Guided by the tenets of this theory, this study examined how the Daily Graphic sets the agenda for public discourse on the disasters of January 2015 and June 2015 and the underlying issues that impinge on the agenda being set.

\subsection{Agenda Setting in the Media}

McCombs and Shaw (1977) point out that agenda setting is about the transmission of salience and not the determination of opinions about a particular issue. In setting the public agenda, the news media influence the salience or prominence of that small number of issues that come to command public attention. Oyero (2010) citing Severin and Tankard (1997) argues that in agenda setting, the media content is capable of influencing the perception of the audience members on important issues and those that are not. McQuail and Windahl (1993) reiterate that the media do not reflect reality, they filter and shape it by concentrating on a few subjects and this leads the public to perceive those issues as more important than other issues.

\section{Methodology}

The study adopted the qualitative research approach to understand the meaning individuals or groups ascribe to social or human problems (disasters). Content analysis was employed extensively in analyzing the printed texts and 
communication media to be precise. However, ethnographic content analysis was used to locate, identify, retrieve, and analyze how the various national disasters featured in the Daily Graphic in the year 2015 were framed. A purposive sampling technique was used to select the Daily Graphic newspaper as the site for this study. However, the sample size of the study would consist of articles pertaining to national disasters in the Daily Graphic newspaper in January 2015 and June 2015.The study used headlines as the principal unit of analysis in investigating how the print media framed national disasters in the Daily Graphic in 2015. News stories for this study were manually selected and hard copies obtained from the Osagyefo Library at the University of Education, Winneba.

At the beginning of the analysis, the researchers went through all the Daily Graphic newspapers from January 2015 to June 2015 and decided to work on only January 2015 and June 2015 respectively due to the numerous numbers of disaster stories published in the said months. The issues identified were coded. The columns included on the coding instrument are; name of newspaper, date of publication, title of story and thematic categories. This made identification easier and enhanced the tracing of the individual units as well as making sure that the headlines are wounded and categorized into various themes. Thus, the data obtained for this study were coded into five (5) news frames and their subcategories. The following are the five (5) news frames and their sub-categories that came out of the study:

National disasters were framed under the following themes

- Fear - It represents headlines that illicit unpleasant emotions of anxiety, pain and sorrow.

- Action - Refers to a call on readers to do something to prevent a disaster and also used in reference to disasters that actually involved the act of doing something.

- Sympathy - This is used in reference to headlines that stimulates the feeling of pity, compassion and condolence.

- Confusion - This refers to headlines that connotes uncertainty or misunderstanding.

- Violence - This refers to behaviour involving physical force intended to hurt, damage, or kill someone or something.

\section{Findings and Discussion}

- RQ1: How does Daily Graphic frame National Disasters in Ghana?

This research question seeks to know the frames used to cover national disasters in January 2015 and June 2015.

\subsection{Headlines on Disaster}

The table below shows the total number of Headlines on Disaster in the Daily Graphic within the periods January 2015 and June 2015.

\begin{tabular}{|c|c|c|}
\hline Month & Daily Graphic & Frequency \% \\
\hline January & 9 & $20.93 \%$ \\
\hline June & 34 & $79.07 \%$ \\
\hline Total & 43 & $100 \%$ \\
\hline
\end{tabular}

Table 1: Number of Headline Stories on Disaster

The total headlines on disasters stories in the Daily Graphic was 43. Out of that number, 9 headlines representing 20.93\%were captured in the month of January 2015 and 34 headlines representing $79.07 \%$ were captured the month of June, 2015.Given the significance of Headline in making a news story prominent, the space given to Disaster in the Headlines of January 2015 was very low. This suggests that not so much attention was given to the disaster in that month by the paper. However, so much attention was given to Disaster in June 2015 signifying an attachment of importance to the Disaster story of June 2015.

\subsection{Themes Emerging from the Headlines}

\begin{tabular}{|c|c|c|c|}
\hline Themes & $\begin{array}{l}\text { Number of } \\
\text { Stories }\end{array}$ & $\begin{array}{l}\text { Frequency } \\
\%\end{array}$ & Examples \\
\hline Fear & 11 & $25.58 \%$ & $\begin{array}{l}\quad \text { Medical Stores in flames } \\
\text { - } \quad \text { Death toll in June 3rd disaster now } 159 \\
\bullet \quad \text { Apocalypse in Accra }\end{array}$ \\
\hline Action & 16 & $37.21 \%$ & $\begin{array}{l}\text { - Stop acts that cause disasters - Rawlings } \\
\text { Disaster, wake-up call to solve seasonal occurrence } \\
\text { EPA demolishes fuel station } \\
\text { President JM declares } 3 \text { days of National mourning }\end{array}$ \\
\hline Sympathy & 7 & $16.28 \%$ & $\begin{array}{c}\text { Non-Denominational Service for floored and fire victims } \\
\bullet \quad \text { Black Stars donate to flood victims }\end{array}$ \\
\hline Confusion & 8 & $18.60 \%$ & GWCL and GNFS in blame game \\
\hline Violence & 1 & $2.33 \%$ & $\begin{array}{l}\text { Old Fadama residents run riot over demolition of Sodom } \\
\text { and Gomorrah }\end{array}$ \\
\hline Total & 43 & $100 \%$ & \\
\hline
\end{tabular}

Table 2 
In all the five themes outlined in the table above, 43 headline stories were coded, out of that number, the theme of Action received the highest coverage of 16 headlines representing $37.21 \%$. The theme of Fear had 11 headlines representing 25.58\%, it placed second. Theme of Confusion placed third with 8 headline stories representing $18.60 \%$. In the fourth rank was theme of Sympathy, which had 7 headline stories representing 16.28\%. Finally, the theme of Violence received the lowest headline coverage with $2.33 \%$ representing 1 story.

The analysis above shows how the Daily Graphic strategically framed disaster new stories and set the agenda for audience to follow the causes and effects of disasters.

Below are some examples of the headlines captured and the themes that emerged out of them as displayed in the "Examples" column of Table1.2

Headline: "Death toll in June 3rd disaster now 159"

Daily Graphic (June 18, 2015,)

The headline above from the Daily Graphic was purposively framed by the paper to inform its audience on the number of people that had lost their lives after the June 3rd Disaster. Though the Daily Graphic framed the headline and set the agenda on that day for readers to discuss the casualties so far, they also communicated "Fear".

Headline: "Medical Stores in Flames"

Daily Graphic (January 14, 2015)

This news story also depicts "Fear" the moment one reads the headline. This framing of the incident would instill some fear in the audience regarding the impact the disaster would have on health care delivery as the store serves as the Bank for medical supplies to public Health facilities. Reading about the 'store' being in flames suggests a depletion of all the medical supplies currently in stock. This arguably would spark fear in audience regarding the impact on health care delivery.

\subsection{Theme of Action}

Headline: "EPA demolishes fuel station"

Daily Graphic (June 9, 2015)

The headline is about the "Action" Environmental Protection Agency (EPA) took to demolish fuel stations situated on water courses in Accra after the June 3rd Disaster. Many government and private organization pointed accusing fingers at individuals and companies that have their structures on water courses as the causes of the rampant floods in Accra. This framing suggests steps taking to curtail any possible future occurrence.

\subsection{Theme of Sympathy}

Headline: "Non-Denominational Service for flood and fire victims"

Daily Graphic (June 9, 2015)

This news story is about Aglow International Ghana organizing Non-Denominational Service for flood victims of the June 3rd Disaster. With this story, the framing was done to court public sympathy for victims of the June 3rd disaster. It also suggests how the disaster has brought about the need to shelve our individual differences in terms of religious doctrines, and come together as a Nation in serious turmoil to seek God's intervention in the lives of those affected. This was put into consideration because the media framed that story to get the attention of the audience. The "Sympathy" theme is evident in the headline story.

\subsection{Theme of Confusion}

Headline: "GWCL and GNFS in blame game"

Daily Graphic (2015, January 16)

The story above automatically signals the reader to sense that there is "Confusion" somewhere. The story was about Ghana Water Corporation Limited and Ghana National Fire Service blaming each other for some of the delay in quenching most of the fire outbreaks in January.

\subsection{Theme of Violence}

Headline: "Old Fadama residents run riot over demolition of Sodom and Gomorrah" Daily Graphic (June 22, 2015)

The headline above depicts "Violence". The moment a reader sets an eye on the above headline the first image that comes to mind is a violent scene. Old Fadama, popularly known as Sodom and Gomorrah, is regularly denounced as an obstacle in Accra's journey towards modernity and development by the Accra Metropolitan Assembly (Asare, 2013). The demolishing exercise was done in response to the June 3rd disaster as residents of Sodom and Gomorrah are seen to be inhabiting in structures that are on the water courses, and this impedes the smooth flow of rainwater which intend causes disaster that is floods in the area whenever there is a heavy downpour. How the story was framed in response to the resistance of residents of Sodom and Gomorrah depicted violence and an uncompromising position of the residents for the good of all. The headline could have read "Old Fadama residents resists demolition of Sodom and Gomorrah".

- RQ2. How prominent are disaster news stories in the Daily Graphic?

This research question seeks to ascertain how prominent disaster news stories are in the Daily Graphic in January 2015 and June 2015. Prominence encompasses the space allocated, placement and the frequency of time given to disaster news stories. 
The table below shows the prominence given to disaster news stories.

\begin{tabular}{|c|c|c|c|}
\hline Month & Disaster & Placement in the Newspaper & $\begin{array}{c}\text { Frequency of Coverage (Number } \\
\text { of Days) }\end{array}$ \\
\hline January 2015 & Fire Outbreaks & Front Pages and Middle Pages & 8 days in January 2015 \\
\hline June 2015 & Twin Disaster & Front Pages and Middle Pages & 16 days in June 2015 \\
\hline June 2015 & Demolition Exercises & Front Page and Opinion Pages & 3 days in June 2015 \\
\hline Total & & & 24 days \\
\hline
\end{tabular}

Table 3

The disasters were categorized into three (3), there are Fire Outbreaks for the disasters that occurred in the month of January 2015, Twin Disasters for the June 3rd disaster and Demolition Exercise category came up during the aftermath of the June 3rd disaster.

Frequency of Coverage of disaster news stories totaled 24 days in both disaster months. Some days contained more than a news story on disaster.

The month of January 2015 recorded 8 days of frequency of coverage of disaster news stories, denoting a less prominence in the month under consideration. June 2015 recorded 16 days of coverage of disaster news stories after the disaster occurred, denoting a high prominence given to the Disaster story of the month under consideration. The days were derived from the coding style used, that is, the date the story was covered. The days of the stories did not follow orderly.

In terms of Placement, the placement of the disaster news stories where mostly prominent on the front pages, and the middle pages had similar prominence as well, and the Opinion Pages had limited prominence of disaster news stories.

The prominence given to headlines stories in the Daily Graphic is in sync with the Agenda Setting Theory by McCombs and Shaw and the Framing Theory by Goffman and Entman who are leading authorities in the field of framing since readers are unconsciously informed to think.

\section{Conclusion}

The study sought to ascertain how the print media framed National Disasters and the prominence given to disaster stories. The print media used in the study was the Newspapers, to be precise, the Daily Graphic in Ghana. After collecting, analyzing and interpreting the data, the study revealed that Daily Graphic covered the January 2015 and June 2015 disaster news stories on the front pages, middle pages and Opinion Pages. In total, 8 days was allocated for covering the fire outbreaks in January 2015 and 16 days for the Twin Disaster and Demolition Exercises in June 2015.

The findings of the study have led to the conclusion that the Daily Graphic frames national disasters around the subject of fear, action, sympathy, confusion, and violence. Thus, most of their headlines sought to evoke these feeling among its audience. The prominence given to disasters by the Daily Graphic was also seen to be high for the periods under consideration. This therefore creates an avenue for setting the agenda for discussions disasters for purpose of finding better ways of controlling and probably avoiding those disasters.

\section{References}

i. Ali, Z. S. (2013). Media myths and realities in natural disasters. European Journal of Business and Social Sciences, 2(1), 125-133.

ii. Asare, A. A. (2013). Facing Old Fadama. GhanaWeb. https://www.ghanaweb.com/GhanaHomePage/features/Facing-Old-Fadama-268693

iii. Brown, P., \& Minty, J. (2006). Media Coverage \& Charitable Giving After the 2004 Tsunami. Paper presented at the William Davidson Institute Working Paper No. 855 retrieved from

http://papers.ssrn.com/sol3/papers.cfm?abstract_id=968760

iv. Chaffee, M. \& Berger, W. (1997). Setting the Community Agenda. Journalism \& Mass Communication Quarterly, USA.

v. Chong, D. \& Druckman, J. N. (2007). Framing Theory. Department of Political Science, Northwestern University, Evanston, Illinois 60208

vi. Chyi, H. I. \& McCombs, M. (2004). Media salience and the process of framing: Coverage of the Columbine School Shootings. Journalism and Mass Communication Quarterly, 81(1) 22-35.

vii. Cissel, M. (2012). Media Framing: a comparative content analysis on mainstream and alternative news coverage of Occupy Wall Street. The Elon Journal of Undergraduate Research in Communications 3, No. 1. Strategic Communications Elon University.

viii. Cohen, E. L., Ball-Rokeach, S. J., Jung, J.-Y., \& Kim, Y.-C. (2002). Civic Actions after September 11: Exploring the Role of Multi-level Story telling Prometheus, 20(3), 221-228.

ix. Cutter, Susan L., \& Emrich, C. (2005). "Are Natural Hazards and Disaster Losses in

x. the U.S. Increasing?” Eos, Transactions American Geophysical Union 86:381-83.

xi. Entman, R. M. (1993). "Framing: Toward Clarification of a Fractured Paradigm," Journal of Communication 43:43: 52.

xii. Etymonline (2015). Disaster. http://www.etymonline.com/index.php?term=disaster

xiii. Fernando, J. (2010). Media in Disaster vs Media Disasters Anthropology News. 
xiv. GeoPoll (2018) Report: Ghana Media Measurement Report: Top TV, Radio, and Print Outlets In 2017. Available athttps://www.geopoll.com/blog/ghana-media-measurement-report-top-tv-radio-print-outlets-2017/

xv. Gitlin, Todd (1980). The Whole World Is Watching. Berkeley: University of California Press.

xvi. Gross, K. (2006). Frames, emotional responses and policy opinion. Paper presented at the annual meeting of the International Communication Association, Dresden International Congress Centre, Dresden, Germany

xvii. Houston, J. B., Pfefferbaum, B., \& B., \& Rosenholtz, C.E. (2012). Disaster news: Framing and frame changing in coverage of major U.S. natural disasters, 2000-2010. Journalism \& Mass Communication Quarterly, 89, 606-623.

xviii. International Federation of Red Cross and Red Crescent Societies (IFRC) (2014). What is a disaster? https://www.ifrc.org/en/what-we-do/disaster-management/about-disasters/what-is-a-disaster/

xix. John, R. B. \& Christensen, L. B. (2008). Educational Research: Quantitative, Qualitative and Mixed Approaches (3rdeds). Thousand Oaks, CA: Sage Publications.

xx. Kuypers, J. A. (2006). Bush's war: Media bias and justifications for war in a terrorist age. New York: Rowman \& Littlefield. Liebes, T. (Ed.). (1998). Television's Disaster Marathons. London: Routledge.

xxi. Lindlof T. R. \& Taylor C. B. (2012). Qualitative Communication Research Methods. (2nded). London, Sage Publications.

xxii. Lippmann, W. (1922). Public opinion. New York: Macmillan.

xxiii. Littlejohn, S. W. (2002). Theories of human communication, 7th Ed. Belmont, CA: Wadsworth/Thomson Learning.

xxiv. Zarqa. S. Ali. (2013). Media myths and realities in natural disasters. European Journal of Business and Social Sciences, 21,125-133/ ISSN: 2235 -767X. http://www.ejbss.com/recent.aspxMayner, L., \& Arbon, P. A. (2015). Defining disaster: The need for harmonization of terminology.

xxv. McCombs, M. \& Shaw, D. L. (1972). The Agenda-Setting Function of Mass Media. Public Opinion Quarterly, 36, $176,-176,-187$.

xxvi. McCombs, M. E, \& Shaw, D.L. (1977). The Emergence of American Political Issues. New York. West Publishing Co.

xxvii. McFarlane, A.C. \& Norris, F. H. (2006). "Definitions and Concepts in Disaster Research," in Methods for Disaster Mental Health Research, ed. Fran H. Norris, Sandro Galea, Matthew J. Friedman, and Patricia J. Watson. New York: Guilford.

xxviii. McQuail D. (2005). McQuail's Mass Communication Theory (5th Eds.) London, Sage.

xxix. McQuail D. \& Windahl A. (1993). Agenda Setting Theory. Retrieved June 20, 2016 from http://www.utwente.nl/cw/theorieenoverzicht/Theory\%20clusters/Mass\%20Media/AgendaSetting_Theory.doc./pdf.

xxx. National Disaster Management Organisation Organization (NADMO) (2010). Disasters. https://www.nadmo.gov.gh/

xxxi. National Media Commission (NMC), (NCA Act, 2008). Assembly Press, Ghana.

xxxii. Oyero, 0. (2011). Presenting Children's Rights Issues in Nigeria and Ghanaian Newspaper. Multidisciplinary Journal of the University of Fort Hare.

xxxiii. Perez-Lugo, M. (2004). Media Uses in Disaster Situations: A New Focus on the Impact Phase. Sociological Inquiry, 74(2), 210-225. doi: 10.1111/j.1475-682X.2004.00087.x

xxxiv. Ploughman, P. (1995) “The American print media 'construction' of five natural disasters," Disasters 19(4): 308326.

xxxv. Quarantelli, E. L. (1981). "The Command Post Point of View in Local Mass Communications

xxxvi. Systems," International Journal of Communication Research 7: 57-73.

xxxvii. Quarantelli, E. L. (1985). What is disaster? The need for clarification in definition and conceptualization in research. University of Delaware Disaster Research Center. Article 177.

xxxviii. Reddy, K. V. K., Sindhu, J., \& Bhaskar, N. L. (2020). Knowledge, attitude and practice regarding disaster preparedness among health care professionals: a cross sectional study in a tertiary care teaching, research and referral medical institute in south India. International Journal of Scientific Research, 9(1).

xxxix. Scanlon, J. (2007). Unwelcome Irritant or Useful Ally? The Mass Media in Emergencies.

xl. Scheufele, D. A \& Tewksbury, D (2007). Framing, Agenda Setting, and Priming: The Evolution of Three Media Effects Models. Journal of Communication. 57. 9-20

xli. Severin, W. J. \& Tankard, J. W. (1997). Communication Theories (4th Eds.), pp. 1-20. New York: Longman.

xlii. Tankard, J. W. Jr., (2003). "The Empirical Approach to the Study of Media Framing," pp. 100-101. Mahwah, NJ: Lawrence Erlbaum.

xliii. Wien, C., \& Elmelund-Praesteker, C. (2009). An anatomy of media hypes: Developing a model for the dynamics and structure of intense media coverage of single issues. European Journal of Communication, 24, 183-201.

xliv. World Health Organisation Organization Emergency and Humanitarian Action (2002). Disasters and emergencies: Definitions. Training Package. Addis Ababa. https://apps.who.int/disasters/repo/7656.pdf 